\title{
The Relationship Between Government Expenditures on Education and Economic Growth: The Case of Azerbaijan
}

\author{
Shahriyar Mukhtarov ${ }^{1}$, Ilkin Mammadov ${ }^{2} \&$ Sugra Humbatova $^{1}$ \\ ${ }^{1}$ Azerbaijan State University of Economics (UNEC), Baku Engineering University, Azerbaijan \\ ${ }^{2}$ Azerbaijan State University of Economics (UNEC), Azerbaijan \\ Correspondence: Shahriyar Mukhtarov, Azerbaijan State University of Economics (UNEC), Baku Engineering \\ University, Azerbaijan.
}

Received: February 5, 2020

Accepted: March 3, 2020

Online Published: March 14, 2020

doi:10.5430/rwe.v11n1p195

URL: https://doi.org/10.5430/rwe.v11n1p195

\begin{abstract}
This paper investigates the impact of government's education expenditures, gross capital formation and total population on economic growth in Azerbaijan during 1995-2018 using the different cointegration methods, namely, ARDLBT, DOLS, and CCR. The results from cointegration methods approve presence of long-run relationship among the variables. The estimation results show that government's expenditures on education, gross capital formation and total population have a positive and statistically significant impact on economic growth in the long-run. The paper concludes that a concerted effort should be made by policy makers to increase educational investment in order to escelate economic growth.
\end{abstract}

Keywords: Azerbaijan, cointegration, economic growth, government education expenditures

\section{Introduction}

Education is a significant determinant of economic growth in each country and is widely accepted as one of the main conditions to attain better social welfare. Investing in education means investing in human resources, which is one of the main important factors of the production function, that is directly related to the level of development of the country and the living standard. It increases labor efficiency and productivity, and thus creates a qualified labor force that is able to lead the economy to a path of sustainable economic development (Zaman, 2008).

Government spending on education leads more to the accumulation of human capital than to physical capital and social capital, and this contributes significantly to economic growth (Dickens et al., 2006; Loening, 2004). The expenditures on education can enhance to achieve better educational results due to they contribute to the development of human capital. An investment in human capital, particularly in education, enables each person to make a productive contribution to society. It becomes a crucial influencer of the economy's ability to attain a high level of growth with high wages, low unemployment and a strong social unity. Hence, the effect of spending on education on economic growth is one of the key issues in economic literature. There are several models, like Solow (1956), Lucas (1988) and Romer (1990), that pointed out the human capital result from spending on education as a driving force for economic growth. The social benefits of education are a powerful set of arguments in favor of public investment to attain a social optimum (Harsha, 2004). That is why government spending on education as an investment is an economic issue that is well discussed nowadays. There are many empirical researches that assess the relationship between public spending on education and economic growth. However, they found different results on the link between public expenditure of education and economic growth.

The common view is that the expenditure on education is the crucial to attain sustainable growth (Blankenau et al., 2007: 393). Economic theory provides significantt foundations for this idea. Considering the studies on the importance of human capital, Nelson and Phelps (1966) reached that a better educated labor force would adopt technological developments faster and better mimic technology. Aghion and Howitt (1998) found that human capital accumulation raises the innovative capacity of the economy, thus accelerating growth. Benhabib and Spiegel (1994) indicated that education promotes economic growth, to assist the successful implementation of new technologies designed by others and dissemination of the information that is necessary for comprehending and processing new information. Mankiw, Romer and Weil (1992), Lucas (1998), underlined that the rise in the human capital of the individual can contribute to the productivity of all the factors of production except its own efficiency and thus 
provide a growth-supporting process. Consequently, education makes the workforce needed by the economy more efficient. It also contributes to the development of creative thinking and advanced techniques for working with a more skilled labor force, which is more appropriated to the necessities of a changing economy, and thus formulating important foundations for sustainable economic growth as well as social cohesion (Wykstra, 1971).

Considering all the aforementioned facts, the main purpose of this study is to examine the effect of government's education expenditures, gross capital formation and total population on economic growth in Azerbaijan for the period of 1995-2018.

The contributions of the study are as follows: (a) It evaluates the government education expenditure-economic growth link for Azerbaijani case, which is a rarely examined example under education-income framework, and is a good representative for the similar economies, (b) this is the first study analyzing this link for Azerbaijan by utilizing time-series data, which allows to observe the country-specific features of this relationship.

\section{Literature Review}

The similar studies investigating the relationship between government education expenditures and economic growth are reviewed in this section. There are a lot of studies in economics literature examining the link between education expenditures and economic growth.

Baldacci et al. (2004) employ a system of equations and to evaluate the direct and the indirect channels between social spending, human capital and economic growth. They found a significant and positive direct impact from education and health expenditures to economic growth. Bose et al. (2007) investigated the effect of disaggregated government expenditures on growth. They found that there is a positive impact of educational government expenditures on economic growth.

Li and Kong (2012) examined relationship between education spending and economic growth for China in long-run. Their findings are very similar to Mallick and Dash (2015), where both studies concluded that there is one-way causality relationship between government education expenditures and economic growth. In addition, other research for Bangladesh, Mukit (2012) indicated that there is a positive and statistically significant long-term effect from government education expenditures to economic growth for the period of 1995-2009. Furthermore, Idrees and Siddiqi (2013) for G-7 countries, Mallick et al. (2016) for 14 Asian countries also obtained similar results. Acosta et al. (2013) investigated the impact of government expenditures on long-run growth. Their analysis revealed that only educational expenditures have statistically significant impact on economic growth. Gemmell et al. (2014) investigate the impact of total government expenditures as well as of composition of government expenditures on the long-run GDP levels employing a pooled mean group (PMG) approach. Results of study showed that increases in the share of education in GDP leads to increase in GDP per capita in the long-run. Otieno (2016) analyzed the effect of education expenditure per worker on economic growth in the case of Kenya for the data spanning from 1967 to 2010. The results showed that there is a positively and significantly impact from education expenditure per worker to economic growth in both long-term and short-term. Moreover, Sunde (2017) revealed a long-run relationship between education expenditure and economic growth using the data ranging from 1976 to 2016. In addition to above-mentioned studies, many empirical studies conducted by Landau (1983), Barro (1991), Tamang (2011), Wolff (2001), Bloom et al. (2001), Mayer (2001), Petrakis and Stamakis (2002), Blankenau et al. (2007), Erdoğan and Yıldırım (2009), Riasat et al. (2011), Asteriou and Agiomirgianakis (2011), Koc (2013), Selim et al. (2014), Mekdad et al. (2014), Owusu-Nantwi (2015) also, concluded a positive relationship between education expenditures and economic growth.

On the other hand, studies by Devarajan et al. (1996), Ndiyo (2007), Nurudeen and Usman (2010), Mariana (2015) and Eggoh et al. (2015) obtained a negative link between education expenditures and economic growth. In some studies, such as Nketiah-Amponsah (2009), Griliches (1997), Çetin and Ecevit (2010), Pamuk and Bektaş (2014), reached absence of relationship between these two variables.

In the case of Azerbaijan, several researches conducted by Aliyev and Nadirov (2016), Hasanov et al. (2016), Aliyev et al. (2016), Aliyev and Mikayilov (2016), Mukhtarov and Rustamov (2018), Hasanov et al. (2018) and Mukhtarov et al. (2018) investigated the impact of total government expenditures on economic growth and did not use government's education expenditures.

As can be seen from the literature review, no study has studied the effect of government's education expenditures on economic growth for Azerbaijani case. Hence, the purpose of this paper is to fill in this gap by employing ARDL technique and different cointegration techniques to see long-run cointegration relationship. The findings will suggest to Azerbaijani policy makers considering the role of government's education expenditures in economic growth for 
macro prudential regulation and sustainable development goals and also contribute to the empirical literature for further studies in the case of oil rich developing countries.

\section{Model and Data}

\subsection{Data}

Our study uses annual data over the period 1995-2018 for empirical analysis. All data set have been taken from World Development Indicators of World Bank (WB, 2019). Government expenditure on education (EDUEX) is measured in million constant US dollars. Economic growth (GDP) is measured by real GDP (2010 US \$). Gross capital formation $(\mathrm{K})$ is measured in million constant US dollars while total population $(\mathrm{P})$ is proxied population between the ages 15 to 64 as a percentage of the total population. All the variables have been transformed into natural logarithmic form for consistent and reliable empirical results.

\subsection{Methodology}

We analyze relationship between government's expenditures on education, gross capital formation, total population and economic growth employing the different cointegration techniques. Our empirical analysis will cover the following stages. First, we will check non-stationarity characteristics of variables. The Augmented Dickey Fuller unit root test (Dickey and Fuller, 1981, ADF) will be used for this exercise.

Second, for testing the cointegration relationship the Bounds Testing approach to cointegration (Pesaran et al, 2001) is utilized. First, the Bounds Testing Approach to Autoregressive Distributed Lagged (ARDL, Pesaran and Shin, 1999; Pesaran et al, 2001) model is employed to see long-run relationship as a main tool due to it outperforms all the alternative cointegration methods in small samples, which is the case here in this research. Then the Dynamic Ordinary Least Squares (DOLS) and Canonical Cointegrating Regression (CCR) are employed for the robustness check.

The above-mentioned methods are not discussed in this study as they are extensively used in many studies, in order to save space and do not to bother readers with the econometric complications. The detailed information about these methods has been mentioned in Dickey and Fuller (1981), Phillips and Hansen (1990), Park (1992), Pesaran and Shin (1999), Pesaran et al, (2001) and others.

\section{Empirical Results and Discussion}

First, we should test the stationarity properties of the used variables. We use the ADF unit root test, for this purpose. Results of unit root testing are presented in Table 1. We found that the EDUEX, GDP and K are non-stationary at their levels but they are stationary at first difference, being integrated of order one, I(1), while P is stationary at its level, hence we can test them for the cointegration. If some variables are being integrated of order one I(1) and others are being integrated of order zero I(0), the first-best solution will be using The Bounds test for cointegration.

Table 1. Results of ADF unit root tests

\begin{tabular}{llllll}
\hline \multirow{2}{*}{ Variable } & \multicolumn{2}{l}{$\begin{array}{l}\text { Panel A: } \\
\text { Level }\end{array}$} & \multicolumn{2}{c}{$\begin{array}{l}\text { Panel B: } \\
\text { 1st difference }\end{array}$} & Result \\
\cline { 2 - 6 } & $k$ & Actual value & $k$ & Actual value & \\
\hline$E D U E X$ & 0 & -0.8802 & 0 & $-3.9852^{* * *}$ & $\mathrm{I}(1)$ \\
\hline$G D P$ & 0 & -0.8612 & 0 & $-3.4456^{* *}$ & $\mathrm{I}(1)$ \\
\hline$K$ & 2 & -1.5562 & 1 & $-3.2606^{* *}$ & $\mathrm{I}(1)$ \\
\hline$P$ & 1 & $-5.7551^{* * *}$ & 1 & -.8287 & $\mathrm{I}(0)$ \\
\hline $\begin{array}{l}\text { Notes: Maximum lag order is set to two and optimal lag order (k) is selected based on } \\
\text { Schwarz criterion in the ADF test; *, ** and *** accordingly indicates rejection of null } \\
\text { hypothesis at 10\%, 5\% and 1\% significance levels; critical values are taken from the } \\
\text { table prepared by MacKinnonun (1996). Time period: 1995-2018. }\end{array}$ \\
\hline
\end{tabular}

The Bounds test for cointegration results are provided at the right side of Table 2 . The cointegration test approved the existence of the long-run relationship among the variables. Therefore, we conclude that there is a cointegrating relationship among the variables. Finally, we use DOLS and CCR methods as a further robustness check alongside the ARDL in estimating the long-run coefficients. We bring together the estimated long-run coefficients from all 
the four different methods for the comparison purpose in Table 2. The residuals of the model are tested for Gauss-Markov conditions and all the results are in line with the requirements, the model also tested for misspecification and concluded that there is no misspecification problem.

Table 2. Cointegration and long-run estimation results

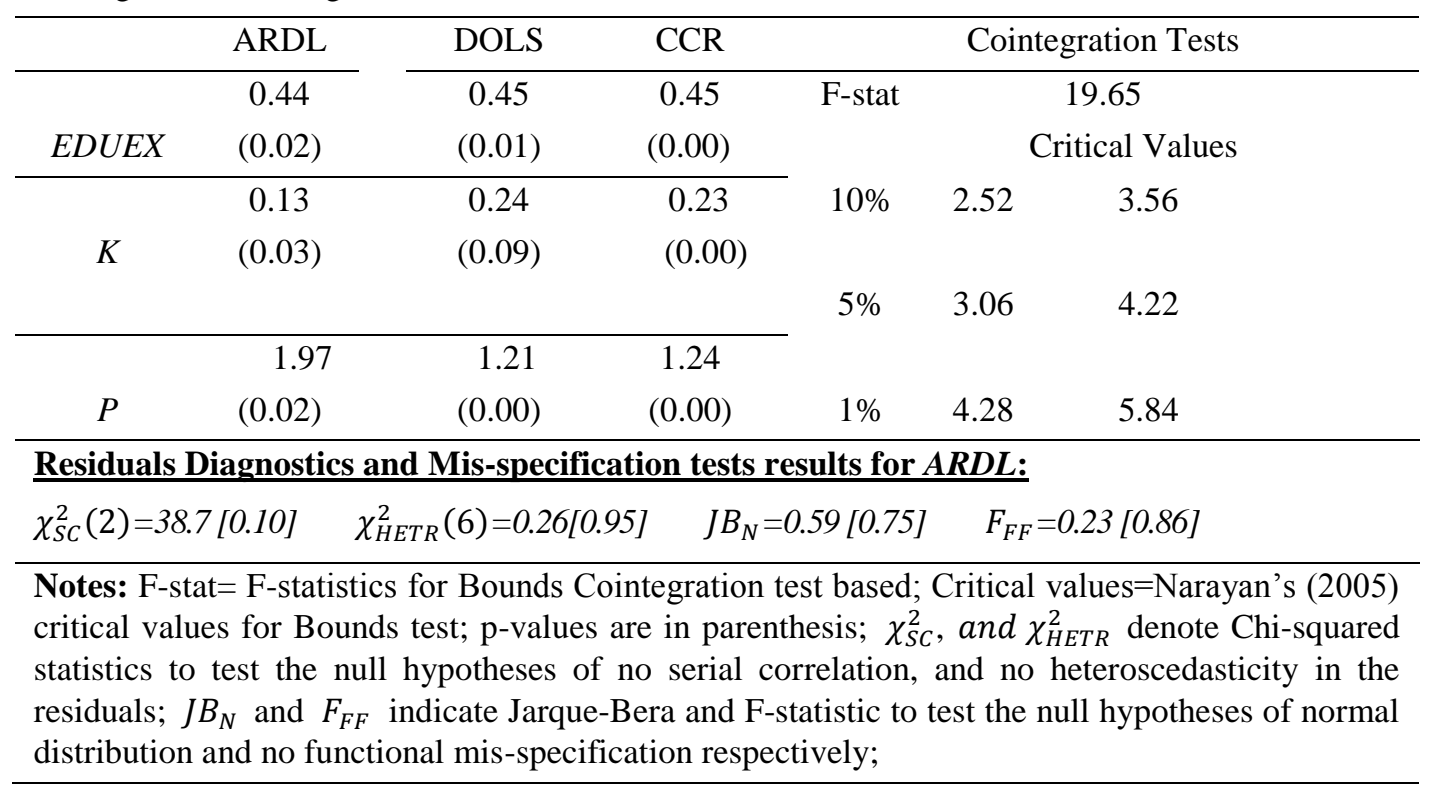

We give priority to the ARDL and discuss it little bit in detail as it outperforms all the alternative cointegration methods in small samples, which is the case here in this research. Table 2 reports the impact of government's education expenditures on economic growth in long-run. We conclude that EDUEX has a positive and statistically significant effect at $5 \%$ level on economic growth. The results indicate that a $1 \%$ rise in government's education expenditures, raises economic growth by $0.44 \%$. Our results are in line with the findings of Mukit's (2012) for 14 Asian countries, Idrees and Siddiqi (2013) for G-7 countries, Owusu-Nantwi (2015) for Ghana, Otieno (2016) for Kenya for Kenya and Sunde (2017) for Mauritius. In addition, the impact of gross capital formation on economic growth is a positive and statistically significant at the 5\% level. This indicates that a $1 \%$ increase in gross capital formation results in $0.13 \%$ increase in economic growth. It implies that an increase in capital raises economic growth. We also find that, the impact of the population proxied by population between the ages 15 to 64 as a percentage of the total population is statistically significant with positive sign, which is consistent with the theory.

\section{Conclusion}

The study examines the relationship between government's expenditures on education, gross capital formation, total population and economic growth. For this purpose, different cointegration techniques (ARDLBT, DOLS and CCR) were employed to estimate the long-run relationship among the variables. Our empirical evidences approve that cointegration presents among the variables. This implies that there is a long-run link between economic growth, gross capital formation, total population and government's expenditures on education in Azerbaijan. Results of the estimations revealed that government's education expenditures, gross capital formation and total population have statistically significant and a positive impact on economic growth. It means that an increase in government's education expenditures, gross capital formation and total population raises economic growth.

The obtained positive effect of government's education expenditures to economic growth reveals that investment in education can increase productivity and efficiency of people, thus generates skilled labor force result in economic growth by the improvements of production in Azerbaijan. Both government's education expenditures and have a positive impact on economic growth, it gains a special importance for Azerbaijani policy makers to formulate convenient investment policies. Thus, the productive spending on education can leads to the development of human capital which can in return, to hold the use of advanced technology in the production process by eliminating costs of adoption. Considering this finding, government may increase the productive government's expenditures on education to give appropriate and sufficient financial support to education system in Azerbaijan. These should include to boost educational investment improving the quality of the labor force. Hence, policymakers in Azerbaijan and similar 
countries should consider the role of government's education expenditures in economic growth for achieving sustainable development.

\section{Acknowledgements}

We are grateful to attendants of the $37^{\text {th }}$ International Scientific Conference on Economic and Social Development "Socio Economic Problems of Sustainable Development", for their comments and suggestions that have helped to improve considerably the paper; nonetheless, we are of course responsible for all errors and omissions. Finally, the views expressed in this paper are those of the authors and do not necessarily represent the views of their affiliated institutions.

\section{Conflicts of Interest}

The authors declare no conflict of interest.

\section{References}

Acosta, Ormaechea, S., \& Morozumi, A. (2013). Can a Government Enhance Long-Run Growth by Changing the Composition of Public Expenditure?. IMF Working Paper, No. 13/162.

Aghion, P., \& Howitt, P. (1998). Endogenous Growth Theory. MIT Press. Cambridge, Mass.

Aliyev, K., \& Mikayilov, C. (2016). Does the budget expenditure composition matter for long-run economic growth in a resource rich country? Evidence from Azerbaijan. Academic Journal of Economic Studies, 2(2), 147-168.

Aliyev, K., \& Nadirov, O. (2016). How fiscal policy affects non-oil economic performance in Azerbaijan?. Academic Journal of Economic Studies, 2(3), 11-30.

Aliyev, K., Dehning, B., \& Nadirov, O. (2016). Modelling the Impact of Fiscal Policy on Non-Oil Gdp in a Resource Rich Country: Evidence from Azerbaijan.

Asteriou, D., \& Agiomirgianakis, G. M. (2001). Human capital and economic growth-time series evidence from Greece. Journal of Policy Modelling, 481-489.

Baldacci, E., Clements, B., Gupta, S., \& Qiang, C. (2004). Social Spending, Human Capital, and Growth in Developing Countries: Implications for Achieving MDGs. IMF Working Paper, No. 04/217.

Barro, R. J. (1991). Economic growth in a cross section of countries. Quarterly Journal of Economics, 106(2), 407-443.

Benhabib, J., \& Spiegel, M. (1994). The role of human capital in economic development: evidence from aggregate cross-country data. Journal of Monetary Economics, 34, 143-173.

Benos, N. (2005). Fiscal policy and economic growth: empirical evidence from OECD countries. Retrieved November 22, 2018, from http://mpra.ub.uni-muenchen.de/19174

Blankenau, W. F., \& Simpson, B. S. (2004). Public education expenditures and growth. Journal of Development Economics, 73(2), 583-605.

Blankenau, W. F., Nicole, B. S., \& Tomljanovich, M. (2007). Public education expenditures, taxation and growth: linking data to theory. American Economic Review, 97(2), 393-397.

Bloom, D. E., Canning, D., \& Sevilla, J. (2001). Economic growth and the demographic transition. NBER Working Paper No. 8685.

Bose, N., Emranul, M. H., \& Osborn, D. R. (2007). Public expenditure and economic growth: a disaggregated analysis for developing countries. The Manchester School, 75(5), 533-556.

Chandra, A. (2011). Nexus between government expenditure on education and economic growth: empirical evidences from India. Revista Româneasca pentru Educatie Multidimensionala, 6, 73-85.

Devarajan, S., Vinaya, S., \& Heng, F. (1996). The composition of public expenditure and economic growth. Journal of Monetary Economics, 37, 313-344.

Dickens, W. T., Sawhill, I., \& Tebbs, J. (2006). The Effects of Investing in Early Education on Economic Growth. Policy Brief, No-153, The Brookings Institutions.

Dickey, D., \& Fuller, W. (1981). Likelihood Ratio Statistics for Autoregressive Time Series with a Unit Root. Econometrica, 49, 1057-1072.

Eggoh, J., Houeninvo, H., \& Sossou, G. A. (2015). Education, health and economic growth in African countries. Journal of Economic Development, 40(1), 93-111. 
Erdoğan, S., \& Yıldırım, D. Ç. (2009). Türkiye'de eğitim-iktisadi büyüme ilişkisi üzerine ekonometrik bir inceleme. Bilgi Ekonomisi ve Yönetimi Dergisi, 4(2).

Gemmell, N., Kneller, R., \& Sanz, I. (2014). Does the Composition of Government Expenditure Matter for Long-Run GDP Levels?. University of Wellington, Victoria Business School Working Paper, No. 10/2014.

Griliches, Z. (1997). Education, human capital, and growth: a personal perspective. Journal of Labor Economics, 15(1), 330-344.

Hasanov, F., Mammadov, F., \& Al-Musehel, N. (2018). The Effects of Fiscal Policy on Non-Oil Economic Growth. Economies, 6(2), 27.

Hasanov, F., Mikayilov, C., Yusifov, S., \& Aliyev, K. (2016). Impact of Fiscal Decentralization on Non-Oil Economic Growth in a Resource-Rich Economy. Eurasian Journal of Business and Economics, 9(17), 87-108.

Idrees, A. S., \& Siddiqi, M. W. (2013). Does Public Education Expenditure Cause Economic Growth? Comparison of Developed and Developing Countries. Pakistan Journal of Commerce and Social Sciences, 7(1), 174-183.

Karaarslan, E. (2005). Kamu kesimi eğitim harcamalarının analizi. Maliye Dergisi, 149, 36-73.

Kibritçioğlu, A. (1998). İktisadi büyümenin belirleyicileri ve yeni büyüme modellerinde beşeri sermayenin yeri. A. Siyasal Bilgiler Fakültesi Dergisi, 53, 207-230.

Landau, D. (1983). Government expenditure and economic growth: a cross-country study. Southern Economic Journal, 49, 783-92.

Lau, L. J., Jamison, D. T., \& Louat, F. F. (1991). Education and Productivity in Developing Countries: An Aggregate Production Function Approach. World Bank Working Paper No. 612.

Li, J., \& Kong, L. (2012). Equilibrium relationship between education and economic growth. Advances in Applied Economic and Finance, 2(3), 403-406.

Loening, J. L. (2004). Time Series Evidence on Education and Growth: The Case of Guatemala, 1951-2002. Revista de Analises Economico, 19(2).

Lucas, R. E. (1988). On the mechanics of economic development. Journal of Monetary Economics, 22, 3-42.

Mallick, L., \& Dash, D. P. (2015). Does Expenditure on Education Affect Economic Growth in India? Evidence from Cointegration and Granger Causality Analysis. Theoretical and Applied Economics, 22(4), 63-74.

Mallick, L., Das, P. K., \& Pradhan, K. C. (2016). Impact of educational expenditure on economic growth in major Asian countries: Evidence from econometric analysis. Theoretical and Applied Economics, 2(607), 173-186.

Mankiw, N. G., Romer, D., \& Weil, D. N. (1992). A contribution to the empirics of economic growth. Quarterly Journal of Economics, 152, 407-437.

Mariana, D. R. (2015). Education as a determinant of the economic growth: the case of Romania. Procedia-Social and Behavioral Science, 197, 404-412.

Mayer, D. (2001). The long-term impact of health on economic growth in Latin America. World Development, 29(6), 1025-1033.

Mekdad, Y., Dahmani, A., \& Louaj, M. (2014). Public spending on education and Economic Growth in Algeria: Causality Test. International Journal of Business and Management, 2(3), 55-70.

Mukhtarov, S., \& Rustamov, U. (2018). Fiskal Siyasətin İqtisadi Artıma Təsirlərinin Qiymətləndirilməsi: Azərbaycan Nümunəsi. II International Scientific Conference of Young Researchers, Baku Engineering University, 527-531.

Mukhtarov, S., Rustamov, U., \& Gasimov, I. (2018). Evaluation of Fiscal Policy Impact on Economic Growth: The Case of Azerbaijan. ASERC Journal of Socio - Economic Studies, 1(1), 82-90.

Mukit, D. M. (2012). Public expenditure on education and economic growth: the case of Bangladesh. International Journal of Applied Research in Business, Administration \& Economics, 1(4), 10-18.

Narayan, P. K. (2005). The Saving and Investment Nexus for China: Evidence from Cointegration Tests. Applied Economics, 37, 1979-1990.

Ndiyo, N. A. (2007). A Dynamic Analysis of Education and Economic Growth in Nigeria. The Journal of Developing Areas, 41(1), 1-16. 
Nelson, R., \& Phelps, E. (1966). Investment in humans, technological diffusion and economic growth. American Economic Review, 56, 69-75.

Nketiah-Amponsah, E. (2009). Public spending and economic growth: evidence from Ghana (1970-2004). Development Southern Africa, 26(3), 477-497.

Nunes, A. (2003). Government expenditure on education, economic growth and long waves: the case of Portugal. Paedagogica Historica, 39, 559-581.

Nurudeen, A., \& Usman, A. (2010). Government expenditure and economic growth in Nigeria, 1970-2008: A disaggregated analysis. Business and Economics Journal, 2, 1-11.

Otieno, D. (2016). The Role of Educational Investment on Economic Growth and Development in Kenya. Journal of Education and Practice, 22(7), 68-81.

Owusu-Nantwi, V. (2015). Education Expenditures and Economic Growth: Evidence from Ghana. Journal of Economics and Sustainable Development, 6(16), 69-77.

Pesaran, M. H., Shin, Y., \& Smith, R. J. (2001). Bound Testing Approaches to the Analysis of Level Relationships. Journal of Applied Econometrics, 16, 289-326.

Pesaran, M., \& Shin, Y. (1999). An autoregressive distributed lag modeling approach to cointegration analysis. In S. Strom, (Ed.), Econometrics and Economic Theory in the 20 ${ }^{\text {th }}$ Century: The Ragnar Frisch centennial Symposium. Cambridge University Press, Cambridge.

Petrakis, P. E., \& Stamatakis, D. (2002). Growth and educational levels: a comparative analysis. Economics of Education Review, 21, 513-521.

Phillips, P. C. B., \& Hansen, B. E. (1990). Statistical inference in instrumental variables regression with I(1) processes. Review of Economics Studies, 57(1), 99-125.

Rebelo, S. (1991). Long-run policy analysis and long-run growth. The Journal of Political Economy, 99(3), 500-521.

Riasat, S., Atif, R. M., \& Zaman, K. (2011). Measuring the impact of educational expenditures on economic growth: evidence from Pakistan. Educational Research, 2(13), 1839-1846.

Romer, P. M. (1986). Increasing returns and long-run growth. The Journal of Political Economy, 94(5), 1002-1037.

Selim, S., Purtaş, Y., \& Uysal, D. (2014). G-20 ülkelerinde eğitim harcamalarının ekonomik büyüme üzerindeki etkisi. Optimum Ekonomi ve Yönetim Bilimleri Dergisi, 1/2, 93-102.

Shaw, G. K. (1997). Policy implications of endogenous growth theory. A Macroeconomics Reader, Brian Snowdon, \& Howard R. Vane (Eds.). London and New York: Routledge, pp. 616-627.

Solow, R. (1956). A Contribution to the Theory of Economic Growth. Quarterly Journal of Economics, 70(1), 65-94.

Sunde, T. (2017). Education Expenditure and Economic Growth in Mauritius: An Application of the Bounds Testing Approach. European Scientific Journal, 13(22), 70-81.

Sylwester, K. (2000). Income inequality, education expenditures and growth. Journal of Development Economics, 63(2), 379-398.

Tamang, P. (2011). The impact of education expenditure on India's economic growth. Journal of International Academic Research. 11(3), 14-20.

Teles, V., \& Andrade, J. (2008). Public investment in basic education and economic growth. Journal of Economic Studies, 35(4), 352-364.

Tsakloglou, P., \& Cholezas, I. (2005). Education and inequality in Greece. IZA Discussion Papers, 1582, 1-15.

Wolff, E. N. (2001). The role of education in the postwar productivity convergence among OECD countries. Industrial and Corporate Change, 10(3), 735-759.

World Bank (WB). (2019). World development indicators. Retrieved October 11, 2019 from, https://data.worldbank.org/indicator/

Wykstra, R. A. (1971). Education and the Economics of Human Capital. New York: Free Press.

Zaman, K. (2008). An Investigation for Pro-Poorness of Government Educational Policy in Pakistan (1991 - 2007). 2nd International Conference on Assessing Quality in Higher Education, 1st-3rd December, 2008, Lahore Pakistan. 